\title{
Positioning Eco-Tourism for Improving Destination Image of Bali Indonesia
}

\author{
I Gusti Bagus Rai Utama
}

Management Study Program, Economics and Humanities Departement

Dhyana Pura UniversityBali, Indonesia

Coressponding author: raiutama@undhirabali.ac.id

\begin{abstract}
ARTICLE INFO
ABSTRACT

Received

Ecotourism attractions in this study include: (1) Bali Marine Park, (2) Bali

20 November 2014

Elephant Safari Park, (3) Bali Barat (West Bali) National Park, (4) Bali

Accepted

Butterfly Park, (5) Bali Reptile Park, (6) Sangeh Monkey Forest, (7) Ubud

22 February 2015

Botanic Garden, and (8) Bali Botanic Garden based on the attributes of

Available online "facility, attractiveness, accessibility, and service". This study utilized quantitative method, specifically exploratory research method and conclusive research method based on previous research and existing theories, in order to achieve the research objectvies with the goal to generate new findings. Based on multidimensional scaling analysis, the perception of Bali Botanic Garden is similar to that of Sangeh Monkey Forest and Bali Barat National Park. While not in the same category as Bali Botanic Garden, the similarity coordinate of Ubud Botanic Garden is so close that it is a considerable competitor to Bali Botanic Garden. The ecotourism attractions perceived to have similarities are Bali Butterfly Park and Ubud Botanic Garden. Another grouping based on similarity are Bali Marine Park and Bali Elephant Safari Park, whose similarity coordinates are quite distant from the other ecotourism attractions.
\end{abstract}

Keywords: botanical garden, ecotourism, forest, marine, park, tourism.

\section{Introduction}

\section{Background}

The role of tourism for economic development in the province of Bali has shown an increasing trend from year to year. According to Pitana and Gayatri (2005), the role of tourism can be seen from its contribution to employment and regional Gross Domestic Product (GDP). From the employment perspective, in 1998 employment in the tourism sector reached $38 \%$ of all employment in Bali. This figure increased when compared to 1995 at $34.14 \%$, and the expected increase will continue to occur from year to year. The increasing role of tourism for Bali's development from year to year is likely to be caused by many factors. One of which is the high desire of tourists (especially foreign tourists) to visit Bali.
Data from the Seminar on Japanese Tourism held on 25-26 February 2002 by the ASEAN-Japan Center on Japanese Travel Marketing Data and Basic Text, specifically the sub-section "The Top Ten of The Most Desired Resorts in Asia", put Bali at the first place in the category of the most desired resort destinations in Asia. This could be a primary assumption to answer why Bali as a tourist destination is still interesting for foreign tourists, particularly from Japan but also possibly for a wider scale target market. Placement of Bali as the top ten of the most desired resort destinations in Asia indicates the importance of destinations including Bali to always focus on the development and preservation of the tourism attractions and attractions that have been greatly admired by tourists, and to combine the various sectors whenever possible. To at least to maintain the pre2001 position of Bali attempts are needed to create a touch of comfort for tourists. 
To maintain or improve the image of Bali as a tourist destination appealing to tourists from around the globe, it is necessary to know the dynamics of tourists' perception on Bali as corrective information aimed for improvement (self-evaluation) or for the development of new or existing tourist attractions. Sudibya (2002) identified several nature-based tourism or "ecotourism" attractions that have been widely known by foreign and domestic tourists since these attractions have been included in the list of tour packages sold by various travel agencies catering for Bali. The ecotourism attractions include: (1) Bali Marine Park, (2) Bali Elephant Safari Park, (3) Bali Barat (West Bali) National Park, (4) Bali Butterfly Park, (5) Bali Reptile Park, (6) Sangeh Monkey Forest, (7) Ubud Botanic Garden, and (8) Bali Botanic Gardens in Bedugul. Specialized tourism product offerings based on eco and nature is one of the differentiation efforts to increase the appeal of Bali as a tourism destination.

\section{Current Status Ecotourism and Activities can be done in Bali}

Bali Safari and Marine Park in Gianyar (Southeast Bali), as part of the Taman Safari Indonesia and a member of WAZA (The World Associations of Zoo and Aquariums), SEAZA (The South East Asians Zoo Associations), CBSG (Conservations Breeding Specialist Group) and PKBSI (Indonesian Zoological Parks Associations), is at the frontline of wildlife conservation in Indonesia and is actively involved in ensuring the future survival and well-being of many Indonesian animal species through education and conservation programs such as the conservation and release of Bali Mynah, Sumatran Elephant, and Sumatran Tiger (see picture 1).

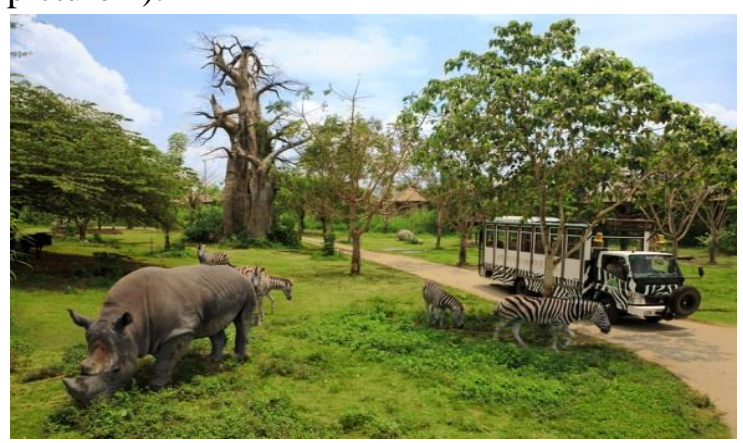

Picture 1. Bali Safari and Marine Park Source: http://www.balisafarimarinepark.com

http://ojs.unud.ac.id/index.php/eot
Bali Barat National Park (Northwest Bali). The Bali Barat (West Bali) National Park is a mountainous area consisting primarily of monsoon forest, mangrove forest (310 ha.), lowland rain forest, savanna, sea grass vegetation (40 ha.), coral reefs (810 ha.), sandy beaches, and both shallow and deep sea waters $(3,520$ ha.). The park is surrounded by six villages with a varied ethnic population (Balinese, Javanese, Madurese and Bugis). These villages are either governed by the districts of Buleleng (northern villages) or Jembrana (western villages). Accessibility and land use within the National Park is bound to a strict zoning system that defines the degree of activities permitted. The peninsular Prapat Court, with its extensive web of footpaths, is the most accessible part of the park. The cape is cut off from the rest of the reserve by the main road Singaraja-Gilamanuk as well as by the forestry plantations inland of the Gulf accept (see picture 2).

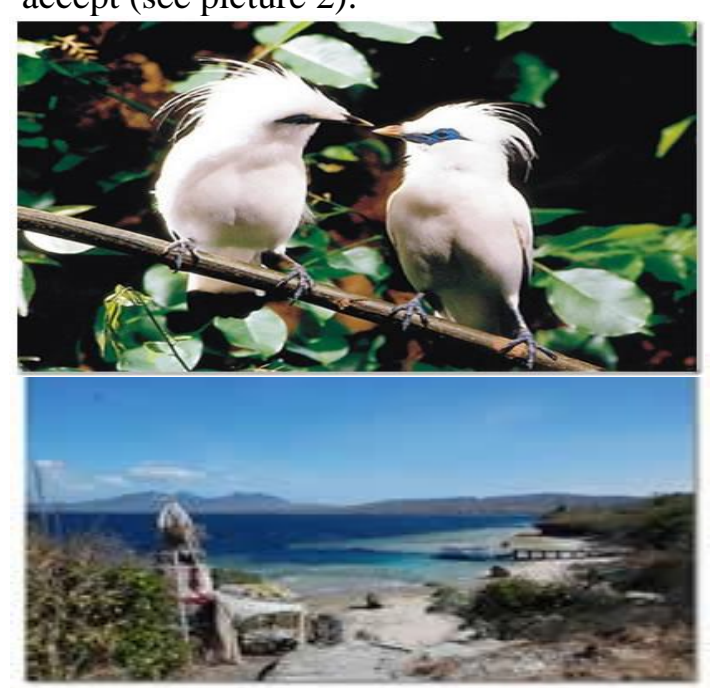

Picture 2. Bali Barat National Park Source:http://www.northbali.info/nature/bali_ barat_national_park.php

Bali Butterfly Park (West-central Bali) is a butterfly and insect conservation facility that exhibits a wide range of specimens through its park grounds of approximately 3,000 sqm located in the village of Wanasari, $6.5 \mathrm{~km}$ north of the Tabanan city and $30 \mathrm{~km}$ the northwest of Denpasar, Bali's administrative capital. The park claims to be the largest of its kind in Asia. The butterfly park is a convenient stopover on excursions to the island's northern region via Tabanan. Here, visitors can experience an educational tour to see hundreds of butterflies from 15 known 
species that thrive in Indonesia's tropics, as well as various other insects and arachnids in extensive and informative displays (see picture 3).
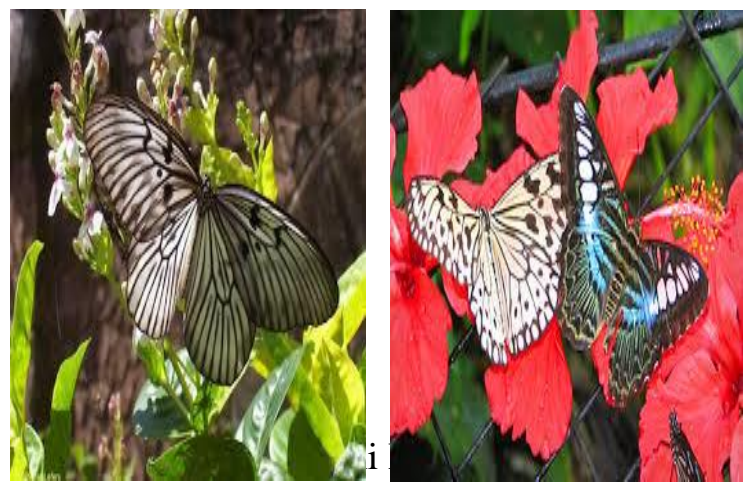

Source: http://www.dewabalitours.com

Bali Botanic Garden is located at Bedugul area in the middle of the island about $60 \mathrm{~km}$ from capital city Denpasar, in central Tabanan regency and bordering the northern Buleleng regency. More than 2000 species of plants are preserved at this botanical garden, representing plants from montane areas of eastern Indonesia: Bali, Nusa Tenggara, Sulawesi, Maluku and Papua. New plants are acquired from commercial nurseries, arboreta, botanic gardens, plant breeding programs and collecting expeditions (see picture 4)
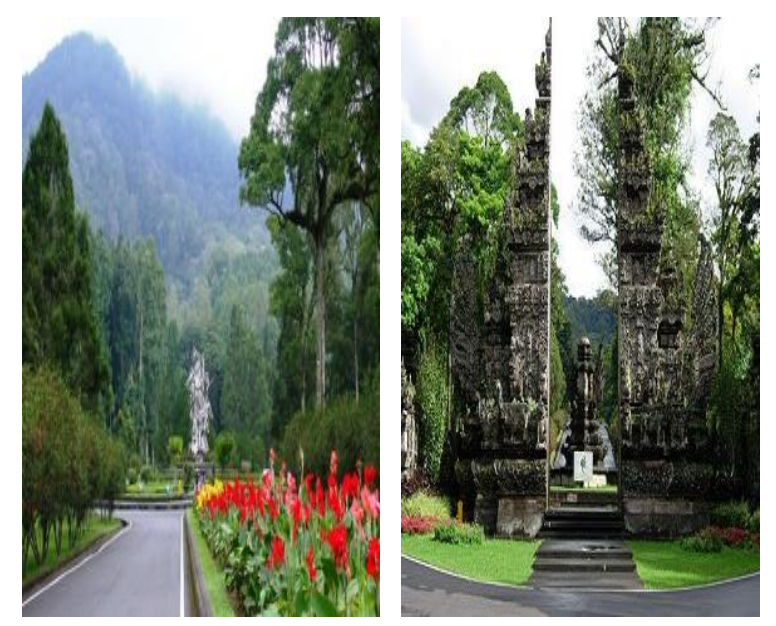

Picture 4. Bali Botanic Garden

Source: http://bali.panduanwisata.id

Sangeh Monkey Forest is located near to Sangeh village, Abiansemal (South central Bali). The six hectares of this monkey forest are filled with giant nutmeg trees capable of growing as high as 40 meters. The main attractions here are the hordes of Balinese monkeys inhabiting both the trees and the holy

http://ojs.unud.ac.id/index.php/eot temple, Pura Bukit Sari, found at the heart of the forest. The monkeys of the forest are believed to be sacred and will approach anyone paying respects at the temple (see picture 5).

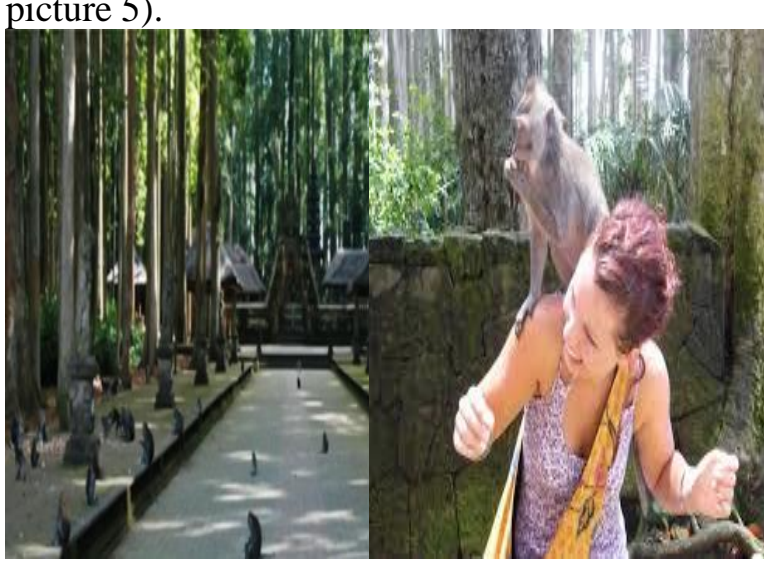

Picture 5. Sangeh Monkey Forest Source: http://www.indonesiatourism.com/bali/sangeh.html

Ubud Botanic Garden was established by a German expatriate, Stefan Reisner, and his Indonesian wife. The site, located in Central Bali at Kutuh Kaja village near the renowned art center of Ubud, on the banks of a river gorge, is held on a 30-year lease from the local village. It has a botanical collection of local and exotic species and a range of Theme Gardens: a great fountain, a fern garden, a chocolate garden, a heliconia grove hill, fragrant floors, a meditation court, a bamboo grove, a water lily pond, a rain forest observation post, a bromeliad garden and an alang-alang trail (see picture 6
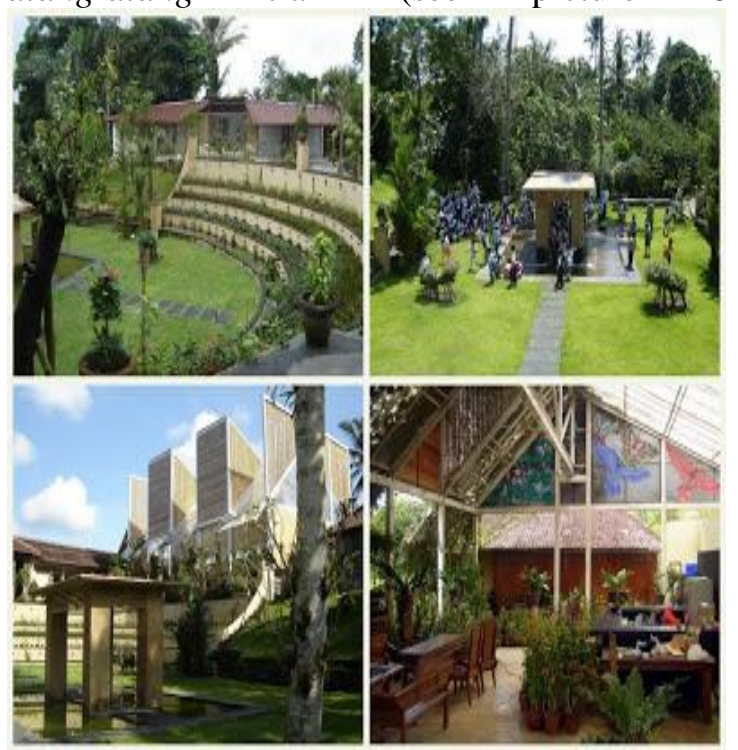

Picture 6. Ubud Botanic Garden Source:

http://botanicalgardenforsale.blogspot.com

e-ISSN: 2407-392X. p-ISSN: 2541-0857 
Bali Reptile Park is located adjacent to the Bali Bird Park, and claims to have the most complete collection of reptiles in Southeast Asia. The park hosts an 8-meter reticulated python, one of the largest snakes in captivity. There is also an extensive collection of Indonesian monitor lizards, in addition to the world-renowned giant pre-historic Komodo Dragons that can reach lengths up to 3 meters. The wildlife sanctuary pulls a large number of visitors due to its wide collection of rare birds and animals (see picture 7)

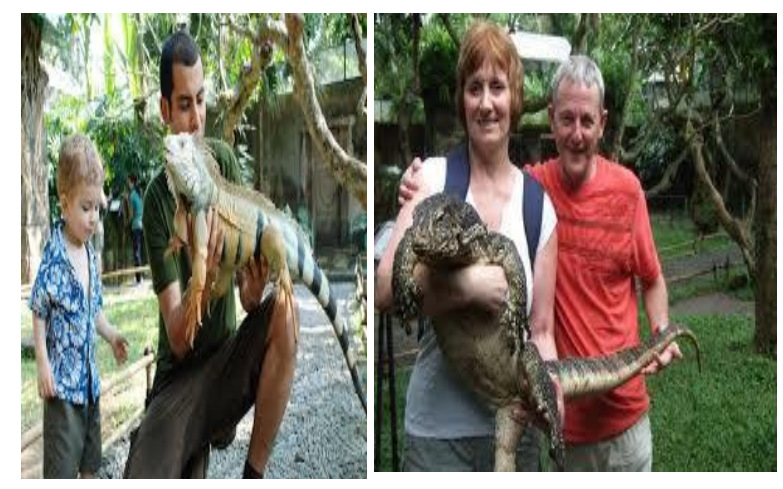

Picture 7. Bali Reptile Park

Source: http://onlinebalidriver.com

\section{The Conceptual of the perception and product positioning}

According to Simamora (2000), there are two sources of perception: direct perception and indirect perception. Indirect perception is formed from the various media used by producers to introduce their products in the form of a human voice, beautiful words and numbers printed in mass media. Meanwhile, direct perception is formed from the senses of sight, hearing, smell, taste, and touch. Direct perception can be further differentiated based on its source into three types of perception: (1) first is the perception of a product derived from indicators that directly relate to a given product. These indicators include, for example, how large are the crowds visiting a shopping center or the number of certain products circulating in public. (2) Second is the perception obtained after exposure or comparison to similar products or other similar attractions, such Cibodas Botanic Garden in Bandung is considered better than Bali Botanic Gardens in size and collection. (3) Third is the perception formed from direct observation, which is the most important because it is derived from a person's direct observation of and interaction with a specific situation.

According to Rusmini (2001), perception is one's perspective on things. Positive perception will encourage someone to purchase a product, whereas negative perception would deter someone from buying the product. Heibing and Cooper in Kasali (1998: 526) stated that perception is the raw material to establish product positioning and then to build a certain image of that product in the eyes of consumers within the target market, relative to similar products or competitors. Furthermore, Mowen quoted by Kasali (1998) defined perception as a process by which individuals are exposed by information, which is then processed in the memory, and then interpreted as information. Perception is expected to form from direct observations by visitors or consumers on the attributes of Bali Botanic Garden, among other ecotourism destinations in Bali, which will provide positioning information for these ecotourism attractions and also provide a general description on the positioning of similar ecotourism attractions in Bali.

\section{Methodology}

Respondents were determined using accidental sampling method, which is the sampling method that applies to all foreign tourists who happened to be visiting in Bali (see Picture 8) during the duration of the research and considered able to provide answers about their perceptions of ecotourism in Bali. In this study, the sample size was determined using the Slovin formula with the degree of error $e=0.10$ with the desired margin of error of only $10 \%$. 


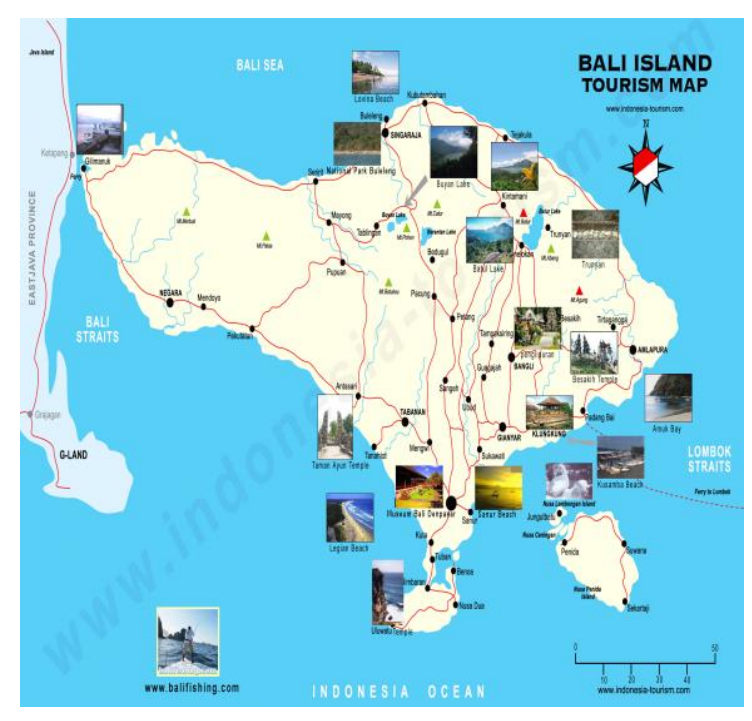

Picture 8. Bali Tourism Map

Source: www.indonesia-tourism.com

Since the average number of foreign tourists amounted to $N=1,464,995$ annually, then the sample is equal to $n=100$ respondents using the formula $n=N /\left(1+N e^{2}\right)$. The attractions of ecotourism in this study include: (1) Bali Marine Park, (2) Bali Elephant Safari Park, (3) the Bali Barat National Park, (4) Bali Butterfly Park, (5) Bali Reptile Park, (6) Sangeh Monkey Forest, (7) Ubud Botanic Garden, and (8) Bali Botanic Garden using the attributes: facilities, attractions or attractiveness, accessibility, and service.

Data analysis technique used in this research is Multidimensional Scaling (MDS). Multidimensional Scaling, according Simamora (2000), is one of the procedures used to visually map the perceptions and preferences of respondents in a geometrical mapping. According Kuncoro (2003), Multidimensional Scaling aims to measure the difference of an attraction in a multidimensional space based on the common perceptions of respondents of that attraction. The difference is reflected by the relative distances between attractions in the multidimensional space. MDS is also called perceptual mapping, which means a procedure that allows researchers to determine the perceived image of an attraction. The goal of MDS is to transform consumer ratings on similarity or preferences into relative distances depicted in a multidimensional space.

\section{Results and Discussion}

Based on the findings and data analysis using MDS or multidimensional scaling, a depiction of the coordinates for each ecotourism attraction was obtained. Corresponding coordinates were be generated in the positioning map for each ecotourism attraction as depicted in the Picture 9.

\section{Individual differenceses (weighted) Euclidean distance model}

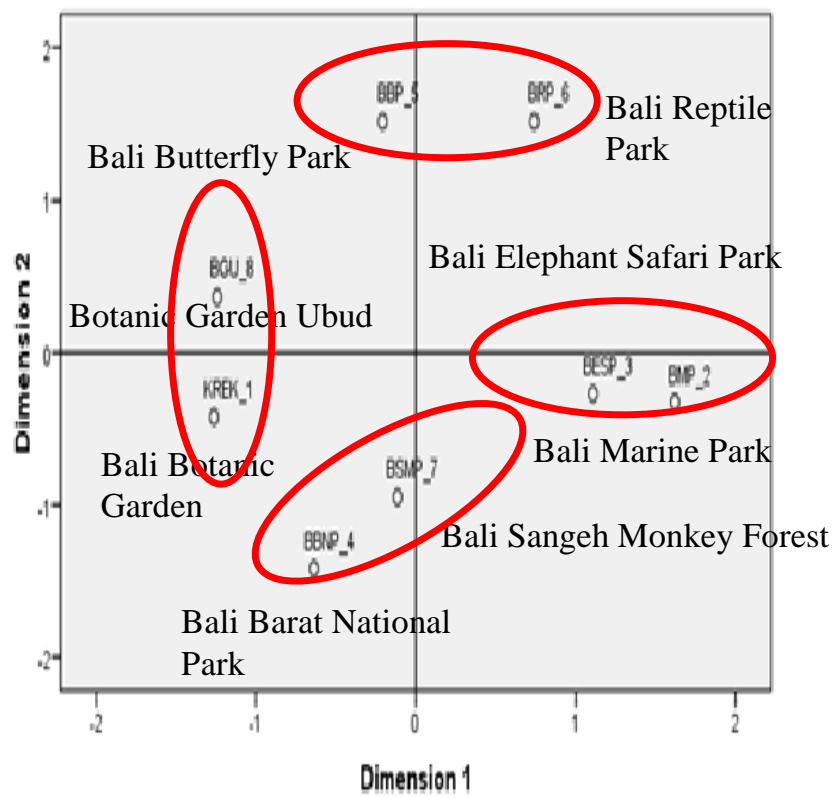

Picture 9. Positioning map of each ecotourism attractionin Bali

The findings on the perception of the respondents based on assessment similar types of ecotourism attractions illustrated that the closest distance in positioning of "paired attractions" were the results of respondents' perception of attractions have close resemblance or similarity to one another. Conversely, if respondents consider the ecotourism attractions as having considerable differences form one another; this is shown by the distance between said attractions on the MDS map.

[1] Eco-tourism attraction (BGU_8), i.e., Ubud Botanic Garden, although not within the same matrix as Bali Botanic Gardens, Ubud Botanic Garden is considered very close in multidimensional scale with (KREK_1) Bali Botanic Garden.

[2] Bali Butterfly Park (BBP_5), on the other hand, is within one matrix with the 
ecotourism attraction Ubud Botanic Garden (BGU_8). Bali Butterfly Park's (BBP_5) coordinates are close to Bali Reptile Park (BRP_6), which share no resemblance to the group.

[3] Ecotourism attractions in close competition with one another are Bali Marine Park (MBP_2) and Bali Elephant Safari Park (BESP_3) and their coordinates are considerably far enough away from resemblance to other similar attractions.

[4] Respondents' perception on Bali Botanic Garden (KREK_1) indicates that its nearest competitor is Sangeh Monkey Forest (BSNF_7) and Bali Barat National Park (BBNP_4) because these attractions are perceived to have similarities. In the observations of the researcher, these three ecotourism attractions share similar typology of tourists who usually visit the attractions, which is largely large tourist groups as in groups of public or private employees, students, families, and so on.

\section{Conclusion and Recommendation}

\section{Conclusion}

The results of multidimensional scaling analysis showed that Bali Botanic Garden is perceived as similar to Sangeh Monkey Forest and Bali Barat National Park. For the ecotourism attraction Ubud Botanic Garden, although not within the same group as Bali Botanic Garden, its coordinates are very close to that of Bali Botanic Garden, which means that Ubud Botanic Garden can be a noteworthy competitor for Bali Botanic Garden. The group of ecotourism attractions considered to have close resemblance or similarity to one another is the Bali Butterfly Park and Ubud Botanic Garden. Another group based on perceived likeness or similarity includes Bali Marine Park and Bali Elephant Safari Park and their coordinates are far enough away from the resemblance to other similar attractions.

\section{Recommendation}

Positioning analysis by measuring the perception of tourists on similar tourism attractions can only describe groups of ecotourism attractions based on the perception of common attributes but have yet to answered which attributes are considered similar and which are considered different, so a more indepth research should be conducted using correspondence analysis to further analyze the advantages of each type of similar tourism attractions in question.

\section{References}

Kasali, R. (1998) Membidik pasar Indonesia: segmentasi, targeting, dan positioning. Gramedia Pustaka Utama.

Kuncoro, M. (2003) 'Metode riset untuk bisnis dan ekonomi', Jakarta: Erlangga.

Pitana, I. G. and Gayatri, P. G. (2005) 'Sosiologi pariwisata', Yogyakarta: Andi.

Rusmini, M. (2001) 'Manajemen Pemasaran', Andi Offset. Yogyakarta.

Simamora, H. (2000) 'Manajemen Pemasaran Internasional', Jakarta: Salemba Empat.

Sudibya, B. (2002) 'Pengembangan Ecotourism di Bali: Kasus Bagus Discovery Group', Makalah disampaikan pada Ceramah Ecotourism di Kampus STIM-PPLP Dhyana Pura, Dalung, Kuta pada tanggal, 14. 